\title{
Comparison of physiochemical property, phytochemical contents, and biological activity of soy sauce added with bitter melon powder
}

\author{
Chung Eun Hwang ${ }^{1}$, Dong Hee Lee ${ }^{2}$, Ok Soo Joo ${ }^{1}$, Hee Yul Lee ${ }^{1}$, \\ $\mathrm{Su}$ Cheol Kim ${ }^{1}$, Kyung Sook Park ${ }^{1}$, Bong Sik Um ${ }^{1}$, Kye Man Cho ${ }^{1 *}$ \\ ${ }^{1}$ Department of Food Science, Gyeongnam National University of Science and Technology, Jinju 52725, Korea \\ ${ }^{2}$ Gyeongbuk Institute for Bioindustry, Andong 36728, Korea
}

\section{여주분말 함유 간장의 이화학적 특성, phytochemical 함량 및 생리활성 비교}

\author{
황정 은 $^{1} \cdot$ 이동희 ${ }^{2} \cdot$ 주옥수 ${ }^{1} \cdot$ 이희 율 ${ }^{1} \cdot$ 김수철 $^{1} \cdot$ 박경숙 $^{1} \cdot$ 엄봉식 $^{1} \cdot$ 조계 만 $^{*}$ \\ 1경남과학기술대학교 식품과학부, ${ }^{2}$ 경북바이오산업연구원
}

\begin{abstract}
In this study, contetnts of phenolic acid and isoflavone, and biological activities of soy sauce were compared the soy sauce added bitter melon powder (BMPs). After the fermentation, pHs were decreased from $5.83(0 \%$ BMP), $5.47(5 \%$ BMP), and $5.32(10 \%$ BMP) to 5.28, 5.36, and 5.16 at 90 days, whereas the acidities of soy sauce were increased from $0.06 \%, 0.07 \%$, and $0.09 \%$ to $0.30 \%, 0.28 \%$, and $0.36 \%$ at 90 days, respectively. In addition, the salinities of soy sauce were decreased, while viable cell numbers including Bacillus and yeast were increased. The contents of total phenolic, isoflavone-aglycone, and phenolic acid and antioxidant and a-glucosidase inhibition activities were significantly increased for 90 days, while the isoflavone-glycoside contents were decreased. In Particular, soy sauce with 10\% BMP at 90 days showed the highest contents of glutamic acid (GA, 9,876.09 mg/100 mL) and $\gamma$-aminobutyric acid (GABA, $325.02 \mathrm{mg} / 100 \mathrm{~mL}$ ) contents than among other samples. Additionally, the radical scavenging activities (DPPH, ABTS, - OH, and FRAP) and a-glucosidase inhibition activities of soy sauce with $10 \%$ BMP at 90 days were shown to be high $96.07 \%, 97.27 \%, 59.47 \%, 1.98 \%$, and $79.96 \%$, respectively.
\end{abstract}

Key words : antioxidant, bitter melon, soy sauce, isoflavones, phenolic acids

\section{서 론}

간장은 소금물에 메주를 30-40일간 담가 우려낸 뒤 그 국물을 떠내어 달여서 만들어지며 예로부터 음식의 간을 맞추는데 쓰는 흑갈색 액체의 조미료로 사용되어져 왔다. 특히 간장은 콩을 이용한 전통 발효식품 중 가장 대표적이 며 발효 중 생성되는 아미노산에 의해 구수한 맛과, 당에 의한 단맛, 소금에 의한 짠맛, 유기산에 의한 신맛이 어우러 져 간장의 품질을 형성한다(1).

*Corresponding author. E-mail : kmcho@gntech.ac.kr Phone : 82-55-751-3272, Fax : 82-55-751-3279

Received 22 November 2017; Revised 20 December 2017; Accepted 22 December 2017.

Copyright (c) The Korean Society of Food Preservation. All rights reserved.
간장의 주성분인 콩은 단백질의 대명사로 알려져 있으나 이 외에도 기능성 물질인 이소플라본을 함유하고 있다. 발 효 과정을 거치지 않은 생콩에는 일반적으로 약 $25 \%$ 의 glycosides 형태와 $80 \%$ 가량의 malonyl-glycosides 형태, 그 리고 5\%의 acetyl-glycosides 형태와 약 $2 \%$ 미만의 aglycones 형태가 존재하는 것으로 알려져 있다(2). 한편 이러한 콩이 발효(간장, 된장, 청국장 등)됨에 따라 미량에 불과하던 aglycones 함량은 30-80\%까지 증가한다고 보고되어있다 (3). 또한 간장은 항산화(4,5)나 면역개선(6)등의 여러 생리 활성 효과가 밝혀지면서 이제는 더 이상 조미식품이 아닌 세계적으로도 각광받고 있는 식품이다(7).

여주(Momordica charantia L.)는 우리나라에서 여자 또 는 쓴오이라고 불리며 동아프리카, 남아메리카 등에서는 미숙과나 종자 등을 치료 및 예방 목적으로 이용해 오고 있는 1 년생 박과식물이다 $(8,9)$. 여주 특유의 쓴맛 때문에 
우리나라에서는 과거 관상용으로만 재배되다가 여러 효능 들이 밝혀지면서 조금씩 이용하고 있는 추세이다. 여주에 함유되어 있는 monordicin 및 cucurbitacins라는 알칼로이드 물질은 항바이러스나 혈당강하 등의 효능이 있다고 알려져 있다(10). 특히 여주에는 charantin이라는 지용성 물질이 함 유되어 있고 이는 인슐린 분비를 촉진시켜 혈당 강하능이 아주 우수하다 보고되어있다(11-13). 또한 여주에 함유되어 있는 MAP3이라는 단백질은 암세포를 파괴하는 세포를 활 성화 시켜 암세포 증식 억제 효과(14)와 momorcharoside라 는 물질은 DNA 합성을 저해하여 암이 전이되는 것을 방지 할 수 있는 물질로 알려져 있다(15).

여주는 다양한 생리 효능을 지니고 있으나 아직 우리나 라의 경우 여주 관련 연구와 소비는 적은 수준이다. 따라서 본 연구에서는 여주 분말을 첨가하여 간장을 제조하고 항산 화 및 항당뇨 효과를 측정함으로써 기능성 식품 개발과 함께 여주 이용성 증대를 위해 실시하였다.

\section{재료 및 방법}

\section{실험 재료 및 시약}

간장 제조에 사용된 콩은 함양군 농협가공사업소에서 장류용 노란콩을 구입하여 사용하였으며 여주는 경상남도 함양군 소재 천령식품에서 건조분말 형태로 공급받아 사용 하였다. 소맥 코오지 제조에 사용한 밀가루는 경상남도 진 주시 대형마트에서 구입하여 사용하였다. Phenolic acid 표 준품(gallic acid, chlorogenic acid, p-hydrolbenzoic acid, protocatechuic acid, vanillic acid, veratric acid 및 t-cinnamic $\operatorname{acid}(\mathrm{t}-\mathrm{CnA})$ )은 Sigma-Aldrich사(St. Louis, MO, USA)에서 구입하였다. Isoflavone 비배당체(daidzein, glycitein 및 genistein) 역시 Sigma-Aldrich사에서 구입하였고 Folin-Cicalteu phenol, 2,2-diphenyl-1-picrylhydrazyl(DPPH), potassium ferricyanide, trichloroacetic acid(TCA), 2,2'-azino-bis(3ethylbenzothiazoline-6-sulfonic acid) diammonium salt(ABTs), 2,4,6-tri(2-pyridyl)-1,3,5-triazine(TPTZ), 2-thiobarbituric acid, trichloroacetic acid, 2-deoxyribose, $\rho$-nitrophenyl-a-Dglucopyranoside(NPG), a-glucosidase(Type I : from Bakers Yeast) 또한 Sigma-Aldrich사에서 구입하여 사용하였다. 한 편 배당체(daidzin, glycitin 및 genistin)는 Indofine사 (Hillsborough, NJ, USA)에서 구입하여 본 연구에 사용하였 다.

소맥 코오지, 청국장 및 여주 분말 함유 간장 제조 소맥 코오지는 밀가루 $3 \mathrm{~kg}$ 에 Aspergillus oryzae 현탁액 을 골고루 분사시켜 가며 반죽한 후 사각형 틀에 얇게 피고 $25^{\circ} \mathrm{C}$ 에서 48 시간 배양하고 $55^{\circ} \mathrm{C}$ 에서 48 시간 건조 및 분쇄시 켜 제조하였다. 콩은 정선 및 수세하여 12 시간 수침한 후 물기를 제거하고 $121^{\circ} \mathrm{C}$ 에서 1 시간 증자 처리를 하였다. 상
온 $\left(15-25^{\circ} \mathrm{C}\right)$ 으로 식힌 후 미리 배양해둔 Bacillus subtilis CSY191(16) 균주 배양액을 2.5\% 접종하여 3일간 청국장을 띄운 후 $55^{\circ} \mathrm{C}$ 에서 2-3일간 건조하여 분말 형태로 제조하였 다. 한편 청국장 분말과 소맥 코오지 분말은 $15 \%$ 염수에 용해시킨 후 여주 첨가량은 간장 총 부피에 무첨가(대조구) 와 $5 \%$ 그리고 $10 \%$ 에 해당하는 양을 분말 형태로 첨가하여 여주 간장을 제조하였다. 제조된 여주 간장은 총 90 일간 상온에서 보관하며 본 실험에 사용하였다.

\section{$\mathrm{pH}$, 산도, 염도 및 생균수}

$\mathrm{pH}$ 는 간장 시료를 일정량 취하여 $\mathrm{pH}$ meter(MP $220 \mathrm{pH}$ meter, Schwerzenbach, UK)를 사용하여 측정하였다. 산도 는 증류수 $50 \mathrm{~mL}$ 에 간장 시료 $1 \mathrm{~mL}$ 를 첨가하여 용해시킨 후 $0.1 \mathrm{~N} \mathrm{NaOH}$ 용액으로 $\mathrm{pH}$ 8.3까지 중화시킨 후 젖산 양으로 환산하였다. 염도는 적당히 희석한 간장을 염도계 (Atoga ES-421, Atago Co., Tokyo, Japan)로 측정하였다. 한 편 각각의 미생물 배양과 생균수 확인은 고초균의 경우 tryptic soy broth/agar(TSB/TSA) 배지를 사용하였고 효모는 chloramphenicol이 함유된 potato dextrose broth/agar (PDB/PDA) 배지를 사용하였으며 생균수 확인은 평판 도말 법으로 도말한 후 $30^{\circ} \mathrm{C}$ 에서 48 시간 배양한 후 30-300개 사이의 집락수를 선정 및 계수하여 $\log \mathrm{CFU} / \mathrm{mL}$ 로 나타내 었다.

유리아미노산

간장 $1 \mathrm{~mL}$ 에 증류수 $4 \mathrm{~mL}$ 를 가해 $60^{\circ} \mathrm{C}$ 에서 1 시간 가수분 해 시킨 후 $10 \% 5$-sulfosalicylic acid $1 \mathrm{~mL}$ 를 첨가하여 $4^{\circ} \mathrm{C}$ 에 서 2시간 방치시키고 원심분리하여 얻은 상등액을 $0.45 \mu \mathrm{m}$ membrane filter(Dismic-25CS, Toyoroshikaisha, Ltd., Tokyo, $\mathrm{Japan}$ )로 여과시켜 $60^{\circ} \mathrm{C}$ 에서 감압 농축하였다. 농축 후 건조 물에 대하여 $\mathrm{pH} 2.2$ lithium buffer $2 \mathrm{~mL}$ 씩 첨가하여 용해 후 $0.45 \mu \mathrm{m}$ membrane filter로 여과시킨 것을 아미노산 자동 분석기로 분석하였다.

\section{추출물 제조}

간장을 우선 동결 건조하여 얻은 분말을 메탄올에 12 시 간 녹여 추출하고 $0.45 \mu \mathrm{m}$ membrane filter로 여과하여 상등 액을 회수한 것을 추출물로 사용하였다.

\section{Total phenolics 분석}

적당히 희석한 추출물 $0.5 \mathrm{~mL}$ 를 시험관에 분주하고 $25 \%$ $\mathrm{Na}_{2} \mathrm{CO}_{3}$ 용액 $0.5 \mathrm{~mL}$ 를 첨가하여 3 분간 정치시켰다. 이어서 $2 \mathrm{~N}$ Folin-Ciocalteu phenol 시약 $0.25 \mathrm{~mL}$ 를 첨가하여 혼합한 다음 상온에서 1 시간 동안 발색시키고 $750 \mathrm{~nm}$ 에서 분광광 도계(Spectronic 2D, Thermo Co., Califonia, CL, USA)를 이 용하여 측정하였다. 


\section{Isoflavones 화합물 분석}

Isoflavone 함량 분석은 Cho 등(17)의 방법에 따라 High performance liquid chromatography(HPLC, Agilent 1200 series, Agilent Co., Forest Hill, Vic, Australia)로 분석하였다. 분석에 사용된 칼럼은 Lichrophore $100 \mathrm{RP}$ C18 column $(4.6 \times 250 \mathrm{~mm}, 5 \mu \mathrm{m}$, Merck, Darmstadt, Germany)을 사용하 였고 이동상 용매는 $0.2 \%$ 초산이 함유된 HPLC water (solution A)와 $0.2 \%$ 초산이 함유된 acetonitrile(solution B)로 분석하였다. 이동상 조건은 $\mathrm{A}$ 용매 기준으로 0분- $100 \%$, 15 분-90\%, 25분- $80 \%, 35$ 분-75\%, 45 분-65\% 및 50 분-65\%로 유지하였다. 시료는 $20 \mu \mathrm{L}$ 를 주입하였으며, 이동상 속도는 $30^{\circ} \mathrm{C}$ 에서 $1 \mathrm{~mL} / \mathrm{min}$ 으로 유지하였다. 검출기는 diode array detector(DAD)를 사용하여 UV $254 \mathrm{~nm}$ 에서 검출하였다.

\section{Phenolic acids 화합물 분석}

Phenolic acid 함량 분석은 XTerra ${ }^{\mathrm{TM}} \mathrm{RP} \mathrm{C} 8$ 칼럼(4.6×250 $\mathrm{mm}, 5 \mu \mathrm{m}$, Waters Corp., Milford, MA, USA)과 HPLC (Agilent 1200 series, Agilent Co. Forest Hill, Vic, Australia) 을 이용하여 분석하였다. $0.2 \%$ 초산 함유 HPLC water(A 용매)와 $0.2 \%$ 초산 함유 HPLC acetonitrile(B 용매)를 사용 하였고 40 분으로 $60-100 \%$ linear gradient한 것은 $30^{\circ} \mathrm{C}$ 에서 $1 \mathrm{~mL} / \mathrm{min}$ 의 흐름률을 적용하였다. 시료는 $20 \mu \mathrm{L}$ 로 주입하 였고 UV 검출기(Agilent 1200 series, Agilent Co.)의 280 $\mathrm{nm}$ 에서 측정하였다.

\section{항산화 활성 측정}

1,1-diphenyl-2-picrylhydrazyl(DPPH)라디칼 소거능은 Hwang 등(18)의 방법을 약간 변형하여 측정하였다. 추출물의 최종 농도가 $1 \mathrm{mg} / \mathrm{mL}$ 가 되도록 3 차 증류수로 희석한 간장 시료 $0.2 \mathrm{~mL}$ 에 $\mathrm{DPPH}$ 용액 $0.8 \mathrm{~mL}$ 를 가하여 상온에서 30 분간 방치 후 $525 \mathrm{~nm}$ 에서 측정하였다.

2,2-azinobis-(3-ethylbenzo-thiazoline-6-sulphonate)(ABT S) 라디칼 소거능 역시 Hwang 등(18)의 방법에 따라 $7 \mathrm{mM}$
ABTs 용액과 $2.45 \mathrm{mM}$ Potassium persulfate $\left(\mathrm{K}_{2} \mathrm{~S}_{2} \mathrm{O}_{8}\right)$ 를 $1: 1$ 로 섞고, 암실에서 12-16시간 보관하여 $\mathrm{ABTs}$ radical(ABTS $\left.{ }^{+}\right)$을 형성시켰다. 이후 $732 \mathrm{~nm}$ 에서 흡광도의 값이 $0.7 \pm 0.02$ 가 되도록 메탄올로 희석하였으며 시료 $0.1 \mathrm{~mL}$ 에 ABTS 용액 $0.9 \mathrm{~mL}$ 를 첨가하여 3 분 후에 분광광도계를 이용하여 측정하였다.

Hydroxyl $(\cdot \mathrm{OH})$ 라디칼 소거능은 $10 \mathrm{mM} \mathrm{FeSO} 4 \cdot 7 \mathrm{H}_{2} \mathrm{O}$ EDTA $0.2 \mathrm{~mL}, 10 \mathrm{mM}$ 2-deoxyribose $0.2 \mathrm{~mL}, 10 \mathrm{mM} \mathrm{H}_{2} \mathrm{O}_{2}$ $0.2 \mathrm{~mL}$, 시료 $1.4 \mathrm{~mL}$ 를 혼합하고 $37^{\circ} \mathrm{C}$ 에서 4 시간 동안 반응 시켰다. 이 혼합액에 $1 \%$ thiobarbituric acid와 $2.8 \%$ trichloroaceric acid를 각각 $1 \mathrm{~mL}$ 씩 가하여 $100^{\circ} \mathrm{C}$ 에서 20 분 간 발색시켜 $520 \mathrm{~nm}$ 에서 흡광도를 측정하였다. DPPH 및 $\mathrm{ABTS}$ 의 음성대조구는 시료대신 증류수를 사용하였고 $\cdot \mathrm{OH}$ 라디칼 소거능의 음성 대조구는 $\mathrm{PBS}$ 완충액 $(\mathrm{NaCl} 8.76$ $\mathrm{g}, \mathrm{NaH}_{2} \mathrm{PO}_{3} 0.11 \mathrm{~g}, \mathrm{Na}_{2} \mathrm{HPO}_{3} 0.596 \mathrm{~g}$ )을 사용하여 시료 첨가구와 무첨가구 사이의 흡광도의 차이를 백분율(\%)로 나타내었다.

\section{a-Glucosidase 저해율 측정}

$200 \mathrm{mM}$ sodium phosphate buffer(pH 6.8) $50 \mu \mathrm{L}$ 에 시료와 a-glucosidase 효소 $50 \mu \mathrm{L}$ 를 첨가하여 $37^{\circ} \mathrm{C}$ 에서 10 분간 예비 배양한 후 sodium phosphate buffer(pH 6.8) $100 \mu \mathrm{L}$ 와 $5 \mathrm{mM}$ p-nitrophenol-a-D-glucopyranoside(p-NPG)을 $100 \mu \mathrm{L}$ 를 가 하여 $37^{\circ} \mathrm{C}$ 에서 10 분간 반응시켰다. 이 반응물에 $100 \mathrm{mM}$ $\mathrm{Na}_{2} \mathrm{CO}_{3} 750 \mu \mathrm{L}$ 를 첨가하여 반응을 정지시키고 $420 \mathrm{~nm}$ 에서 흡광도를 측정하고 저해율을 계산하였다. 음성 대조구는 증류수를 사용하였다.

\section{통계처리}

실험 결과는 SPSS 12.0 package를 사용하여 분산 분석을 수행하였고 평균표준편차로 나타내었다.

Table 1. Comparison of $\mathrm{pH}$, acidity, salinity, and viable cell numbers of soy sauce without and with bitter melon powder

\begin{tabular}{|c|c|c|c|c|c|c|}
\hline \multirow{3}{*}{ Contents $^{1)}$} & \multicolumn{6}{|c|}{ Added bitter melon powder concentration (\%) } \\
\hline & \multicolumn{2}{|c|}{0} & \multicolumn{2}{|c|}{5} & \multicolumn{2}{|c|}{10} \\
\hline & 0 day & 90 day & 0 day & 90 day & 0 day & 90 day \\
\hline $\mathrm{pH}$ & $5.83 \pm 0.23^{22)}$ & $5.28 \pm 0.21^{\mathrm{a}}$ & $5.47 \pm 0.23^{\mathrm{a}}$ & $5.36 \pm 0.22^{\mathrm{a}}$ & $5.32 \pm 0.21^{\mathrm{a}}$ & $5.16 \pm 0.21^{\mathrm{a}}$ \\
\hline Acidity (\%, as lactic acid) & $0.06 \pm 0.00^{\mathrm{b}}$ & $0.30 \pm 0.02^{\mathrm{a}}$ & $0.07 \pm 0.01^{\mathrm{b}}$ & $0.28 \pm 0.02^{\mathrm{a}}$ & $0.09 \pm 0.01^{\mathrm{b}}$ & $0.36 \pm 0.02^{\mathrm{a}}$ \\
\hline Salinity $(\%$, as $\mathrm{NaCl})$ & $12.04 \pm 0.42^{\mathrm{a}}$ & $11.06 \pm 0.48^{b}$ & $12.54 \pm 0.42^{\mathrm{a}}$ & $10.95 \pm 0.42^{b}$ & $11.60 \pm 0.43^{\mathrm{b}}$ & $11.39 \pm 0.46^{6}$ \\
\hline \multicolumn{7}{|c|}{ Viable cell numbers $(\log \mathrm{CFU} / \mathrm{mL})$} \\
\hline Bacillus & $8.78 \pm 0.35^{b}$ & $9.42 \pm 0.38^{\mathrm{a}}$ & $8.81 \pm 0.35^{b}$ & $9.40 \pm 0.38^{\mathrm{a}}$ & $8.85 \pm 0.37^{\mathrm{b}}$ & $9.39 \pm 0.35^{\mathrm{a}}$ \\
\hline Yeast & $6.09 \pm 0.24^{\mathrm{b}}$ & $6.16 \pm 0.29^{b}$ & $6.09 \pm 0.24^{b}$ & $7.09 \pm 0.24^{\mathrm{a}}$ & $6.09 \pm 0.28^{\mathrm{b}}$ & $6.58 \pm 0.30^{\mathrm{b}}$ \\
\hline
\end{tabular}

\footnotetext{
${ }^{1)}$ All values are means of determination in three independent experiments.

${ }^{2)}$ All values within a column with different superscript letters are significantly different from each other at $\mathrm{p}<0.05$ by Duncan's multiple range test.
} 


\section{결과 및 고찰}

여주분말 함유 간장의 이화학적 특성 변화

여주분말을 첨가하여 제조한 간장의 이화학적 특성은 Table 1에 나타내었다. $\mathrm{pH}$ 는 여주분말의 첨가량이 많을수 록 조금씩 감소하는 경향을 보였다(0\%-5.83, 5\%-5.47, $10 \%-5.32$ ). 또한 90 일째에는 모든 여주 간장의 $\mathrm{pH}$ 가 아주 조금씩 감소하였고 평균 $\mathrm{pH}$ 는 5.33 을 나타내었다. 한편 $\mathrm{pH}$ 감소에 비례하여 산도는 조금씩 증가하였고 $10 \%$ 여주 간장 이 $0.36 \%$ 로 산도가 가장 높게 측정되어졌으나 큰 차이는 없었다. 염도는 전체적으로 90 일째 조금씩 감소하는 경향 을 나타내었고 $10 \%(11.39 \%), 0 \%(11.06 \%), 5 \%(10.95 \%)$ 첨 가 순으로 염도가 높은 것으로 나타났다. 한편 간장의 생균 수 변화는 여주분말 첨가량에 따른 큰 차이는 보이지 않았 고 대체적으로 90 일째 증가하는 결과를 나타내었다(Table 1).

\section{여주분말 함유 간장의 유리아미노산 함량 변화}

여주분말 함유 간장의 유리아미노산 함량 분석 결과는 Table 2와 같았다. 여주 첨가 간장은 공통적으로 urea가 검출되지 않았다. 비필수 아미노산은 여주 첨가량이 높을 수록 총 함량 역시 증가하는 것으로 나타났다. 여주를 첨가 하지 않은 간장의 경우에는 $4,156.95 \mathrm{mg} / 100 \mathrm{~mL}$, 여주 $5.0 \%$ 첨가 간장은 $6,481.14 \mathrm{mg} / 100 \mathrm{~mL}, 10 \%$ 첨가 간장에서는 $7,512.67 \mathrm{mg} / 100 \mathrm{~mL}$ 가 검출되었다. 90 일째 역시 비필수 아미노산 총 함량이 여주 첨가량에 비례적으로 여주를 첨가 하지 않은 간장의 경우 $11,239.62 \mathrm{mg} / 100 \mathrm{~mL}$ 로 증가하였고 여주 $5.0 \%$ 첨가 간장은 $14,006.49 \mathrm{mg} / 100 \mathrm{~mL}$, 여주 $10 \%$ 첨가 간장은 $19,229.86 \mathrm{mg} / 100 \mathrm{~mL}$ 로 가장 크게 증가하였다. Glutamic acid(GA)는 모든 간장에서 가장 많은 양을 차지하 고 있었으며 90 일째 여주를 첨가하지 않은 간장은 $1,341.33$ $\rightarrow 4,094.78 \mathrm{mg} / 100 \mathrm{~mL}$ 로 증가하였다. $5.0 \%$ 첨가 간장 역시 $2,456.54 \rightarrow 6,050.33 \mathrm{mg} / 100 \mathrm{~mL}$ 로 크게 증가하였고 $10 \%$ 첨가 간장은 $3,400.21 \rightarrow 9,876.09 \mathrm{mg} / 100 \mathrm{~mL}$ 로 여주 간장 중 가장 큰 증가폭을 나타내었다. 한편 비필수 아미노산 (proline, aspartic acid, serine, sarcosine, glycine, a -aminobutyric acid, cystathionine, $\beta$-alanine, $\beta$-aminobutyric acid, aminoethanol, anserine, arginine)과 필수 아미노산 (threonine, valine, methionine, isoleucine, leucine, phenylalanine, lysine, histidine)들은 모두 90 일째에 크게 증가하였다. 특히 혈압저하 효과가 있다고 알려진 $\gamma$-aminobutyric acid (GABA) 역시 여주 첨가량이 높을수록 많은 양이 검출되었 고 90 일째에는 조금씩 증가하였다. 여주를 첨가하지 않은 간장의 경우 $\mathrm{GABA}$ 함량은 $42.46 \rightarrow 84.95 \mathrm{mg} / 100 \mathrm{~mL}$ 로 증가하였고 $5 \%$ 첨가 시에는 $168.34 \rightarrow 170.30 \mathrm{mg} / 100 \mathrm{~mL}$ 로 약간 증가하였고 $10 \%$ 첨가 시에는 $296.21 \rightarrow 325.02 \mathrm{mg} / 100$ $\mathrm{mL}$ 로 증가하였다.

유리아미노산의 생성은 일반적으로 단백질 가수분해에
의해 생성이 되며(19) 이는 발효 미생물이 관여하고 더 나아 가서는 간장을 비롯한 콩 발효식품의 관능적 특성과 영양적 인 특성과 직접적인 관련이 있다(20). Yang 등(21)의 간장 가수분해물 연구 결과에서는 가수분해 처리농도에 따라 생성되는 유리아미노산의 양은 증가한다고 보고하였으며 일반 간장에서는 glutamic $\operatorname{acid}(37.04 \mathrm{mg} / 100 \mathrm{~mL})$, aspartic $\operatorname{acid}(24.27 \mathrm{mg} / 100 \mathrm{~mL})$, leucine $(19.94 \mathrm{mg} / 100 \mathrm{~mL})$, lysine $(18.65 \mathrm{mg} / 100 \mathrm{~mL})$, 및 tyrosine $(16.02 \mathrm{mg} / 100 \mathrm{~mL})$ 등의 대부분의 유리아미노산이 검출되었고 주요 아미노산은 glutamic acid인 것으로 결과를 나타내 본 연구와도 일치하 였다. 한편 Zarkadas 등(22) 역시 주요 아미노산으로 glutamic acid를 제시하였으며 원료 콩이 함유하고 있는 유 리아미노산 조성은 콩 품종에 따른 차이가 있는 것으로 보고하였으며 이는 본 연구와도 유사한 경향을 나타내었다.

여주분말 함유 간장의 phenolic acid 함량 변화

여주분말 함유 간장의 phenolic acid 함량 변화는 Table 3 에 나타낸바와 같았다. 여주분말 함유 간장에서는 모두 7종류의 화합물인 gallic acid, protocatechuic acid, p-hydrobenzoic acid, chlorgenic acid, vanillic acid, vetaric acid, 및 t-cinnamic acid가 검출되었다. 또한 vanillic acid를 제외한 나머지 phenolic acid 화합물들은 모두 90 일째에 증 가한 것으로 나타났다. 또한 90 일째 여주를 첨가하지 않은 간장의 경우 gallic acid 함량은 $140.88 \mu \mathrm{g}$ 이었고 $5 \%$ 첨가 시 $141.24 \mathrm{\mu g}, 10 \%$ 첨가 시 $150.55 \mu \mathrm{g}$ 을 나타내었으며 전체 적으로 여주 분말 첨가량이 많을수록 gallic acid를 포함한 대부분의 phenolic acids 함량이 90 일째에 증가하는 경향을 나타내었다(Table 3). 한편 초기와 90 일째까지 가장 함량이 높았던 p-hydrobenzoic acid는 주요 phenolic acid 화합물인 것으로 나타났으며 여주 첨가량이 많을수록 즉, $0 \%(334.76$ $\mu \mathrm{g} \rightarrow 793.68 \mu \mathrm{g}), 5 \%(398.67 \mu \mathrm{g} \rightarrow 909.04 \mu \mathrm{g}), 10 \%(443.31$ $\mu \mathrm{g} \rightarrow 1027.65 \mu \mathrm{g})$ 로 첨가량이 높아질수록 초기 함량도 많았 으며 90 일째에도 많은 것으로 나타났다. 한편 vetaric acid는 여주 첨가량에 따른 상관관계는 나타나지 않았으며 여주를 첨가하지 않은 경우 90 일째 미량으로 검출되었으며 나머지 간장들 역시 대부분 90 일째 감소하는 경향을 나타내었다. 일부 phenolic acid 화합물들은 증가와 감소의 차이가 조금 씩 있었으나 total phenolic acid 함량은 여주 첨가량이 높을 수록 다음과 같이 크게 증가하였다. $0 \%(605.43 \mu \mathrm{gg} \rightarrow$ $1,175.55 \mu \mathrm{g}), 5 \%(610.27 \mu \mathrm{g} \rightarrow 1,316.30 \mu \mathrm{g}), 10 \%(670.97$ $\mu \mathrm{g} \rightarrow 1,587.44 \mu \mathrm{g})$ (Table 3).

Cho 등(17)의 연구 결과에서는 청국장 발효 시 phenolic acid 중 gallic acid 함량이 증가함을 보고하였고 이는 본 연구 결과와도 완벽히 일치하였다. 하지만 gallic acid를 제 외한 나머지 phenolic acid 화합물들은 감소 혹은 불검출되 거나 미량 검출되어 이 결과는 본 연구와 차이점이 있는 것으로 나타났다. 이러한 phenolic acid 화합물들은 2 차 대 
Table 2. Comparison of free amino acid contents of soy sauce without and with bitter melon powder

\begin{tabular}{|c|c|c|c|c|c|c|}
\hline \multirow{3}{*}{ Contents $^{1)}(\mathrm{mg} / 100 \mathrm{~mL})$} & \multicolumn{6}{|c|}{ Added bitter melon powder concentration (\%) } \\
\hline & \multicolumn{2}{|c|}{0} & \multicolumn{2}{|c|}{5} & \multicolumn{2}{|c|}{10} \\
\hline & 0 day & 90 day & 0 day & 90 day & 0 day & 90 day \\
\hline \multicolumn{7}{|c|}{ Non-essential amino acids } \\
\hline Urea & $\mathrm{ND}^{2)}$ & ND & ND & $\mathrm{ND}$ & $\mathrm{ND}$ & $\mathrm{ND}$ \\
\hline Proline & $291.46 \pm 11.66^{\mathrm{e} 3)}$ & $789.22 \pm 31.57^{\mathrm{b}}$ & $413.78 \pm 16.55^{\mathrm{d}}$ & $1094.72 \pm 43.79^{\mathrm{a}}$ & $468.67 \pm 18.75^{\mathrm{c}}$ & $1029.56 \pm 41.18^{\mathrm{a}}$ \\
\hline Aspartic acid & $189.58 \pm 7.58^{\mathrm{e}}$ & $915.41 \pm 36.62^{\mathrm{c}}$ & $447.39 \pm 17.90^{\mathrm{d}}$ & $1345.67 \pm 53.83^{\mathrm{a}}$ & $443.64 \pm 17.75^{\mathrm{d}}$ & $1214.52 \pm 48.58^{\mathrm{b}}$ \\
\hline Serine & $102.43 \pm 4.10^{\mathrm{e}}$ & $335.48 \pm 13.42^{\mathrm{c}}$ & $202.21 \pm 8.09^{\mathrm{d}}$ & $710.17 \pm 28.41^{\mathrm{a}}$ & $333.21 \pm 13.33^{\mathrm{c}}$ & $576.88 \pm 23.08^{\mathrm{b}}$ \\
\hline Glutamic acid & $1341.33 \pm 53.65^{\mathrm{f}}$ & $4094.78 \pm 163.79^{c}$ & $2456.54 \pm 98.26^{\mathrm{e}}$ & $6050.33 \pm 242.01^{b}$ & $3400.21 \pm 136.01^{\mathrm{d}}$ & $9876.09 \pm 395.04^{\mathrm{a}}$ \\
\hline Sarcosine & $29.23 \pm 1.17^{\mathrm{d}}$ & $156.89 \pm 6.28^{\mathrm{a}}$ & $20.83 \pm 0.83^{\mathrm{e}}$ & $56.33 \pm 2.25^{\mathrm{c}}$ & $89.65 \pm 3.59^{b}$ & $90.59 \pm 3.62^{b}$ \\
\hline Aminoadipic acid & $103.23 \pm 4.13^{\mathrm{b}}$ & $252.68 \pm 10.11^{\mathrm{a}}$ & $6.51 \pm 0.26^{\mathrm{d}}$ & $\mathrm{ND}$ & $12.52 \pm 0.50^{c}$ & $\mathrm{ND}$ \\
\hline Glycine & $186.73 \pm 17.47^{\mathrm{f}}$ & $447.62 \pm 17.90^{c}$ & $216.62 \pm 8.66^{\mathrm{e}}$ & $562.60 \pm 22.50^{\mathrm{a}}$ & $237.26 \pm 9.49^{d}$ & $526.78 \pm 21.07^{\mathrm{b}}$ \\
\hline Alanine & $486.03 \pm 19.44^{\mathrm{d}}$ & $1135.30 \pm 45.41^{\mathrm{a}}$ & $557.84 \pm 22.31^{\mathrm{b}}$ & $426.54 \pm 17.06^{c}$ & $128.08 \pm 5.12^{\mathrm{e}}$ & $1102.92 \pm 44.12^{\mathrm{b}}$ \\
\hline Citrulline & $130.51 \pm 5.22^{\mathrm{e}}$ & $475.22 \pm 19.01^{\mathrm{b}}$ & $219.94 \pm 8.80^{c}$ & $\mathrm{ND}$ & $48.60 \pm 1.94^{\mathrm{f}}$ & $998.07 \pm 39.92^{\mathrm{a}}$ \\
\hline a-Aminobutyric acid & $35.54 \pm 1.42^{\mathrm{d}}$ & $79.46 \pm 3.18^{b}$ & $39.34 \pm 1.57^{\mathrm{d}}$ & $67.31 \pm 2.69^{c}$ & $19.27 \pm 0.77^{\mathrm{e}}$ & $90.51 \pm 3.62^{\mathrm{a}}$ \\
\hline Cystine & $\mathrm{ND}$ & ND & $\mathrm{ND}$ & $84.89 \pm 3.40^{\mathrm{b}}$ & $\mathrm{ND}$ & $97.73 \pm 3.91^{\mathrm{a}}$ \\
\hline Cystathionine & $30.77 \pm 1.23^{\mathrm{c}}$ & $70.26 \pm 2.81^{\mathrm{a}}$ & $30.21 \pm 1.21^{\mathrm{c}}$ & $49.12 \pm 1.96^{b}$ & $31.95 \pm 1.28^{c}$ & $50.24 \pm 2.01^{\mathrm{b}}$ \\
\hline Tyrosine & $438.74 \pm 17.55^{\mathrm{f}}$ & $917.18 \pm 36.69^{c}$ & $546.27 \pm 21.85^{\mathrm{e}}$ & $1188.10 \pm 47.52^{\mathrm{a}}$ & $600.66 \pm 24.03^{\mathrm{d}}$ & $1103.27 \pm 44.13^{\mathrm{b}}$ \\
\hline$\beta$-alanine & $27.82 \pm 1.11^{\mathrm{f}}$ & $134.95 \pm 5.40^{\mathrm{a}}$ & $52.91 \pm 2.12^{\mathrm{e}}$ & $99.30 \pm 3.97^{\mathrm{c}}$ & $63.68 \pm 2.55^{\mathrm{d}}$ & $109.97 \pm 4.40^{\mathrm{b}}$ \\
\hline$\beta$-Aminoisobutyric acid & $101.53 \pm 4.06^{\mathrm{f}}$ & $286.61 \pm 11.46^{\mathrm{a}}$ & $145.86 \pm 5.83^{\mathrm{e}}$ & $207.46 \pm 8.30^{c}$ & $155.73 \pm 6.23^{\mathrm{d}}$ & $234.82 \pm 9.39^{b}$ \\
\hline$\gamma$-Aminobutyric acid & $42.46 \pm 1.70^{\mathrm{e}}$ & $84.95 \pm 3.40^{\mathrm{d}}$ & $168.34 \pm 6.73^{c}$ & $170.30 \pm 6.81^{\mathrm{c}}$ & $296.21 \pm 11.85^{\mathrm{b}}$ & $325.02 \pm 13.00^{\mathrm{a}}$ \\
\hline Aminoethanol & $13.22 \pm 0.53^{\mathrm{e}}$ & $52.19 \pm 2.09^{\mathrm{a}}$ & $27.30 \pm 1.09^{\mathrm{d}}$ & $44.34 \pm 1.77^{b}$ & $33.03 \pm 1.32^{\mathrm{c}}$ & $46.81 \pm 1.87^{b}$ \\
\hline Hydroxyproline & $50.34 \pm 2.01^{\mathrm{b}}$ & $74.34 \pm 2.97^{\mathrm{a}}$ & $46.42 \pm 1.86^{b}$ & $48.51 \pm 1.94^{\mathrm{b}}$ & $49.21 \pm 1.97^{\mathrm{b}}$ & $44.05 \pm 1.76^{b}$ \\
\hline Ornithine & $187.92 \pm 7.52^{\mathrm{c}}$ & $131.21 \pm 5.25^{\mathrm{e}}$ & $152.67 \pm 6.11^{\mathrm{d}}$ & $318.88 \pm 12.76^{\mathrm{a}}$ & $230.87 \pm 9.23^{b}$ & $307.68 \pm 12.31^{\mathrm{a}}$ \\
\hline 1-Methylhistidine & $2.22 \pm 0.09^{e}$ & ND & $244.29 \pm 9.77^{\mathrm{d}}$ & $519.34 \pm 20.77^{\mathrm{a}}$ & $296.94 \pm 11.88^{c}$ & $496.09 \pm 19.84^{b}$ \\
\hline 3-Methylhistidine & $18.20 \pm 0.73^{\mathrm{c}}$ & $44.24 \pm 1.77^{\mathrm{a}}$ & $7.22 \pm 0.29^{\mathrm{d}}$ & $29.89 \pm 1.20^{\mathrm{b}}$ & $19.60 \pm 0.78^{c}$ & $15.69 \pm 0.63^{c}$ \\
\hline Anserine & $129.85 \pm 5.19^{\mathrm{e}}$ & $436.19 \pm 17.45^{\mathrm{a}}$ & $126.57 \pm 5.06^{\mathrm{f}}$ & $344.38 \pm 13.78^{b}$ & $156.43 \pm 6.26^{\mathrm{d}}$ & $313.29 \pm 12.53^{\mathrm{c}}$ \\
\hline Carnosine & $58.68 \pm 2.35^{\mathrm{a}}$ & $64.50 \pm 2.58^{\mathrm{a}}$ & $18.16 \pm 0.73^{c}$ & $57.27 \pm 2.29^{\mathrm{a}}$ & $17.88 \pm 0.72^{\mathrm{c}}$ & $51.44 \pm 2.06^{\mathrm{b}}$ \\
\hline Arginine & $159.13 \pm 6.37^{\mathrm{e}}$ & $260.94 \pm 10.44^{d}$ & $333.92 \pm 13.36^{\mathrm{c}}$ & $531.04 \pm 21.24^{\mathrm{a}}$ & $379.37 \pm 15.17^{\mathrm{b}}$ & $527.84 \pm 21.11^{\mathrm{a}}$ \\
\hline Totals & $4156.95 \pm 166.28^{\mathrm{f}}$ & $11239.62 \pm 449.58^{c}$ & $6481.14 \pm 259.25^{\mathrm{e}}$ & $14006.49 \pm 560.26^{\mathrm{b}}$ & $7512.67 \pm 300.51^{\mathrm{d}}$ & $19229.86 \pm 769.19^{a}$ \\
\hline \multicolumn{7}{|l|}{ Essential amino acid } \\
\hline Threonine & $236.92 \pm 9.48^{\mathrm{f}}$ & $646.58 \pm 25.86^{\mathrm{c}}$ & $276.98 \pm 11.08^{\mathrm{e}}$ & $787.98 \pm 31.52^{\mathrm{b}}$ & $412.65 \pm 16.51^{\mathrm{d}}$ & $985.12 \pm 39.40^{\mathrm{a}}$ \\
\hline Valine & $510.60 \pm 20.42^{\mathrm{e}}$ & $1381.03 \pm 55.24^{\mathrm{a}}$ & $617.51 \pm 24.70^{\mathrm{d}}$ & $1363.37 \pm 54.53^{\mathrm{a}}$ & $645.00 \pm 25.80^{c}$ & $1199.64 \pm 47.99^{b}$ \\
\hline Methionine & $146.65 \pm 5.87^{\mathrm{d}}$ & $403.09 \pm 16.12^{\mathrm{a}}$ & $183.37 \pm 7.33^{c}$ & $351.23 \pm 14.05^{b}$ & $188.00 \pm 7.52^{\mathrm{c}}$ & $364.30 \pm 14.57^{b}$ \\
\hline Isoleucine & $418.09 \pm 16.72^{\mathrm{e}}$ & $1153.41 \pm 46.14^{\mathrm{c}}$ & $505.10 \pm 20.20^{\mathrm{d}}$ & $2048.09 \pm 81.92^{\mathrm{a}}$ & $498.86 \pm 19.95^{\mathrm{d}}$ & $1799.38 \pm 71.98^{\mathrm{b}}$ \\
\hline Leucine & $791.36 \pm 31.65^{\mathrm{e}}$ & $2041.56 \pm 81.66^{\mathrm{c}}$ & $948.03 \pm 37.92^{\mathrm{d}}$ & $2456.32 \pm 98.25^{b}$ & $951.71 \pm 38.07^{\mathrm{d}}$ & $2709.32 \pm 108.37^{\mathrm{a}}$ \\
\hline Phenylalanine & $588.79 \pm 23.55^{\mathrm{f}}$ & $1430.34 \pm 57.21^{\mathrm{b}}$ & $736.69 \pm 29.47^{\circ}$ & $1509.16 \pm 60.37^{\mathrm{a}}$ & $803.98 \pm 32.16^{\mathrm{d}}$ & $1411.86 \pm 56.47^{\mathrm{c}}$ \\
\hline Lysine & $427.10 \pm 17.08^{f}$ & $976.46 \pm 39.06^{\mathrm{c}}$ & $531.54 \pm 21.26^{\mathrm{e}}$ & $1232.93 \pm 49.32^{\mathrm{a}}$ & $613.17 \pm 24.53^{\mathrm{d}}$ & $1200.75 \pm 48.03^{b}$ \\
\hline Histidine & $171.14 \pm 6.85^{\mathrm{f}}$ & $398.56 \pm 15.94^{c}$ & $212.34 \pm 8.49^{\mathrm{e}}$ & $467.56 \pm 18.70^{b}$ & $334.43 \pm 13.38^{\mathrm{d}}$ & $678.90 \pm 27.16^{\mathrm{a}}$ \\
\hline Totals & $3290.65 \pm 131.63^{\mathrm{f}}$ & $8431.02 \pm 337.24^{\mathrm{a}}$ & $3522.24 \pm 140.89^{\mathrm{e}}$ & $6504.79 \pm 260.19^{b}$ & $3700.72 \pm 148.03^{\mathrm{d}}$ & $5975.92 \pm 239.04^{c}$ \\
\hline Total amino acids & $7447.60 \pm 290.90^{f}$ & $19670.64 \pm 786.83^{c}$ & $10003.38 \pm 400.14^{e}$ & $20511.28 \pm 820.45^{\mathrm{b}}$ & $11213.39 \pm 448.54^{\mathrm{d}}$ & $25205.78 \pm 1008.23^{\mathrm{a}}$ \\
\hline Ammonia & $221.66 \pm 8.87^{d}$ & $467.50 \pm 18.70^{\mathrm{a}}$ & $259.74 \pm 10.39^{c}$ & $456.10 \pm 18.24^{\mathrm{b}}$ & $264.68 \pm 10.59^{c}$ & $457.47 \pm 18.30^{b}$ \\
\hline
\end{tabular}

\footnotetext{
${ }^{11}$ All values are means of determination in three independent experiments.

${ }^{2)} \mathrm{ND}$, not detected.

${ }^{33}$ All values within a column with different superscript letters are significantly different from each other at $p<0.05$ by Duncan's multiple range test.
} 
Table 3. Comparison of phenolic acid contents of soy sauce without and with bitter melon powder

\begin{tabular}{|c|c|c|c|c|c|c|}
\hline \multirow{3}{*}{ Contents $^{1)}(\mu \mathrm{g} / \mathrm{mL})$} & \multicolumn{6}{|c|}{ Added bitter melon powder concentration (\%) } \\
\hline & \multicolumn{2}{|c|}{0} & \multicolumn{2}{|c|}{5} & \multicolumn{2}{|c|}{10} \\
\hline & 0 day & 90 day & 0 day & 90 day & 0 day & 90 day \\
\hline Gallic acid & $85.14 \pm 3.41^{(2)}$ & $140.88 \pm 5.64^{b}$ & $83.65 \pm 3.35^{c}$ & $141.24 \pm 2.15^{b}$ & $81.76 \pm 3.27^{\mathrm{c}}$ & $150.55 \pm 6.02^{\mathrm{a}}$ \\
\hline Protocatechuic acid & $32.69 \pm 1.31^{\mathrm{c}}$ & $47.53 \pm 1.90^{\mathrm{b}}$ & $21.87 \pm 0.87^{\mathrm{d}}$ & $53.74 \pm 2.15^{\mathrm{b}}$ & $11.55 \pm 0.46^{\mathrm{e}}$ & $79.47 \pm 3.18^{\mathrm{a}}$ \\
\hline p-Hydrobenzoic acid & $334.76 \pm 13.39^{f}$ & $793.68 \pm 31.75^{\mathrm{c}}$ & $398.67 \pm 15.95^{\mathrm{e}}$ & $909.04 \pm 36.36^{b}$ & $443.31 \pm 17.73^{\mathrm{d}}$ & $1027.65 \pm 41.11^{\mathrm{a}}$ \\
\hline Chlorgenic acid & $25.54 \pm 1.02^{\mathrm{d}}$ & $59.24 \pm 2.37^{\mathrm{a}}$ & $13.79 \pm 0.55^{\mathrm{f}}$ & $34.17 \pm 1.37^{\mathrm{c}}$ & $14.64 \pm 0.59^{\mathrm{e}}$ & $47.83 \pm 1.91^{\mathrm{b}}$ \\
\hline Vanilic acid & $27.39 \pm 1.10^{b}$ & $\mathrm{tr}^{3)}$ & $6.53 \pm 0.26^{\mathrm{d}}$ & $11.05 \pm 0.44^{\mathrm{c}}$ & $39.66 \pm 1.59^{\mathrm{a}}$ & $25.97 \pm 1.04^{b}$ \\
\hline Ventaric acid & $81.56 \pm 3.26^{\mathrm{d}}$ & $110.86 \pm 4.43^{c}$ & $70.22 \pm 2.81^{\mathrm{e}}$ & $135.78 \pm 5.43^{\mathrm{b}}$ & $60.79 \pm 2.43^{\mathrm{f}}$ & $224.59 \pm 8.98^{\mathrm{a}}$ \\
\hline t-Cinnamic acid & $18.35 \pm 0.73^{c}$ & $23.36 \pm 0.93^{b}$ & $15.54 \pm 0.62^{\mathrm{d}}$ & $31.28 \pm 1.25^{\mathrm{a}}$ & $19.26 \pm 0.77^{\mathrm{c}}$ & $31.38 \pm 1.26^{\mathrm{a}}$ \\
\hline Total & $605.43 \pm 24.22^{\mathrm{e}}$ & $1,175.55 \pm 47.02^{\mathrm{c}}$ & $610.27 \pm 24.41^{\mathrm{e}}$ & $1,316.30 \pm 52.65^{b}$ & $670.97 \pm 26.84^{d}$ & $1,587.44 \pm 63.50^{\circ}$ \\
\hline
\end{tabular}

\footnotetext{
${ }^{1)}$ All values are means of determination in three independent experiments.

${ }^{2)}$ All values within a column with different superscript letters are significantly different from each other at $p<0.05$ by Duncan's multiple range test.

${ }^{3)}$ tr, trace $(<0.002 \mu \mathrm{g} / \mathrm{mL})$
}

사산물로 흔히 식용 가능한 식물에 널리 분포한다고 알려져 있다 $(23,24)$. Pratt 등(25)과 Seo와 Morr(26)는 본 연구에서 검출되었던 vanillic acid나 p-hydrobenzoic acid와 같은 여러 phenolics 화합물들은 일반적으로 원료 콩에서는 매우 적은 양만이 존재한다 하였으며 Boo 등(27)은 품종별 여주의 phenolics 함량을 측정한 결과 한국 재래종이 가장 많은 양을 함유한다고 보고하였다. 따라서 본 연구에서 phenolic acid 증가 현상은 본래 여주가 함유하고 있는 것에 기인하여 phenolics 화합물들이 90 일째에 점차적으로 증가한 것으로 판단된다.

여주분말 함유 간장의 total phenolics 함량 변화

여주분말 함유 간장의 total phenolics 함량 변화는 Fig. 1 과 같았다. 간장 담금 직후에는 여주를 첨가하지 않은 간장 의 경우 $1.84 \mathrm{mg} / \mathrm{mL}$ 를 나타내었고 $5 \%$ 첨가 시에는 2.99 $\mathrm{mg} / \mathrm{mL}, 10 \%$ 첨가 시에는 $3.76 \mathrm{mg} / \mathrm{mL}$ 로 여주 첨가량이 높을수록 함량 또한 높았으며 이는 본 연구의 phenolic acid 결과와 완벽히 일치하는 경향을 나타내었다(Fig. 1). 또한 여주 첨가 간장은 90 일째 각각 $4.43 \mathrm{mg} / \mathrm{mL}(0 \%), 4.78$ $\mathrm{mg} / \mathrm{mL}(5 \%)$, 및 $4.95 \mathrm{mg} / \mathrm{mL}(10 \%)$ 로 증가하였다.

Phenolics 화합물은 이미 언급한바와 같이 식물계에 널리 존재하는 천연 항산화제의 대부분을 차지하며 지방질의 산화 및 산화적 스트레스 방어 효과를 나타냄과 동시에 활성산소 제거에도 관여하는 것으로 알려져 있다 $(18,28)$

한편 Choi 등(29)은 흑마늘 첨가량이 많을수록 total phenolics 함량이 증가하는 경향을 나타낸다 하였고 Jang 등(30) 역시 황기 추출액을 $5 \%$ 와 $10 \%$ 첨가 시 함량은 각각 $7.6 \mathrm{mg} / \mathrm{g}$ 및 $10.3 \mathrm{mg} / \mathrm{g}$ 으로 첨가량이 많을수록 total phenolics 함량이 증가함을 보고하였다. Park 등(31)도 천마 를 첨가한 간장에서 숙성 기간이 길어짐에 따라 phenolics 함량 역시 증가함을 보고하여 본 연구와도 동일한 경향을
나타내었고 이는 여주 분말에 함유되어 있는 phenolics 화합 물들에 기인한 것으로 판단된다.

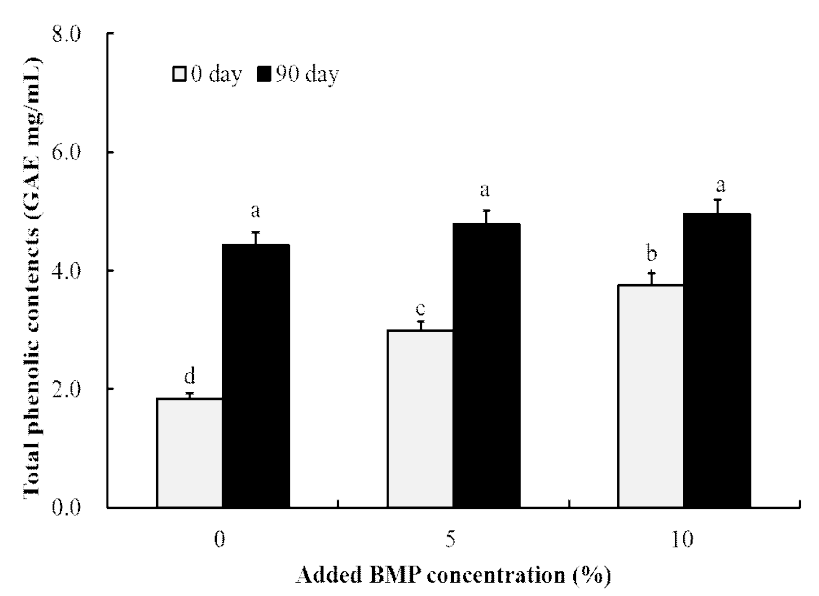

Fig. 1. Comparison of total phenolic contents of soy sauce without and with bitter melon powder (BMP).

All values are means of determination in three independent experiments. All values within a column with different superscript letters are significantly different from each other at $\mathrm{p}<0.05$ by Duncan's multiple range test.

여주분말 함유 간장의 isoflavone 함량 변화

여주 간장의 isoflavone 함량 분석 결과 배당체(daidzin, glycitin, genistin)와 비배당체(daidzein, glycitein, genistein) 형태의 6종류의 isoflavone이 검출되었다(Table 4). 여주 첨 가 간장은 공통적으로 여주 첨가량이 높을수록 초기 배당체 총 함량은 낮은 것으로 나타났고 90 일째 모두 감소하는 것으로 나타났다. 여주를 첨가하지 않은 간장의 경우 초기 배당체 총 함량은 $80.32 \mu \mathrm{g} / \mathrm{mL}$ 에서 $11.78 \mu \mathrm{g} / \mathrm{mL}$ 로 크게 감소하였고 $5 \%$ 첨가 간장은 $55.89 \mathrm{\mu g} / \mathrm{mL} \rightarrow 38.99 \mu \mathrm{gg} / \mathrm{mL}$, $10 \%$ 첨가 간장은 $54.44 \mu \mathrm{gg} \rightarrow 45.28 \mu \mathrm{g} / \mathrm{mL}$ 로 조금씩 감소하 였다(Table 4). 여주를 첨가하지 않은 간장의 비배당체 함량 
Table 4. Comparison of isoflavone contents of soy sauce without and with bitter melon powder

\begin{tabular}{|c|c|c|c|c|c|c|}
\hline \multirow{3}{*}{ Contents $^{1)}(\mu \mathrm{g} / \mathrm{mL})$} & \multicolumn{6}{|c|}{ Added bitter melon powder concentration (\%) } \\
\hline & \multicolumn{2}{|c|}{0} & \multicolumn{2}{|c|}{5} & \multicolumn{2}{|c|}{10} \\
\hline & 0 day & 90 day & 0 day & 90 day & 0 day & 90 day \\
\hline \multicolumn{7}{|c|}{ Glycosides } \\
\hline Daidzin & $25.90 \pm 1.04^{\mathrm{a} 2)}$ & $6.28 \pm 0.25^{\mathrm{d}}$ & $13.21 \pm 0.53^{\mathrm{b}}$ & $11.49 \pm 0.46^{c}$ & $11.69 \pm 0.47^{\mathrm{c}}$ & $11.13 \pm 0.45^{\mathrm{c}}$ \\
\hline Glycitin & $24.94 \pm 1.00^{b}$ & $4.21 \pm 0.17^{\mathrm{c}}$ & $29.22 \pm 1.17^{b}$ & $24.53 \pm 0.98^{\mathrm{b}}$ & $27.27 \pm 1.09^{\mathrm{b}}$ & $31.51 \pm 1.26^{\mathrm{a}}$ \\
\hline Genistin & $29.48 \pm 1.18^{\mathrm{a}}$ & $1.29 \pm 0.05^{\mathrm{c}}$ & $13.46 \pm 0.54^{\mathrm{b}}$ & $2.97 \pm 0.12^{\mathrm{c}}$ & $15.48 \pm 0.62^{\mathrm{b}}$ & $2.64 \pm 0.11^{\mathrm{c}}$ \\
\hline Total & $80.32 \pm 3.21^{\mathrm{a}}$ & $11.78 \pm 0.47^{\mathrm{e}}$ & $55.89 \pm 2.24^{\mathrm{b}}$ & $38.99 \pm 1.56^{\mathrm{d}}$ & $54.44 \pm 2.18^{\mathrm{b}}$ & $45.28 \pm 1.81^{\mathrm{c}}$ \\
\hline \multicolumn{7}{|c|}{ Aglycones } \\
\hline Daidzein & $27.54 \pm 1.10^{\mathrm{d}}$ & $103.85 \pm 4.15^{\mathrm{a}}$ & $50.14 \pm 2.01^{\mathrm{c}}$ & $82.05 \pm 3.28^{b}$ & $52.04 \pm 2.08^{c}$ & $78.55 \pm 3.14^{\mathrm{b}}$ \\
\hline Glycitein & $6.11 \pm 0.24^{c}$ & $24.20 \pm 0.97^{\mathrm{a}}$ & $10.79 \pm 0.43^{\mathrm{c}}$ & $18.34 \pm 0.73^{b}$ & $9.38 \pm 0.38^{c}$ & $17.41 \pm 0.70^{\mathrm{b}}$ \\
\hline Genistein & $15.57 \pm 0.62^{\mathrm{e}}$ & $77.09 \pm 3.08^{\mathrm{a}}$ & $33.46 \pm 1.34^{\mathrm{d}}$ & $62.43 \pm 2.50^{\mathrm{b}}$ & $33.57 \pm 1.34^{\mathrm{d}}$ & $56.65 \pm 2.27^{\mathrm{c}}$ \\
\hline Total & $49.22 \pm 1.97^{\mathrm{e}}$ & $205.14 \pm 8.21^{\mathrm{a}}$ & $94.39 \pm 3.78^{d}$ & $162.82 \pm 6.51^{b}$ & $94.99 \pm 3.80^{\mathrm{d}}$ & $152.61 \pm 6.10^{c}$ \\
\hline Total isoflavone & $129.54 \pm 5.18^{\mathrm{d}}$ & $216.92 \pm 8.68^{a}$ & $150.28 \pm 6.01^{c}$ & $201.81 \pm 8.07^{b}$ & $149.43 \pm 5.98^{c}$ & $197.89 \pm 7.92^{b}$ \\
\hline
\end{tabular}

${ }^{1)}$ All values are means of determination in three independent experiments.

${ }^{2)}$ All values within a column with different superscript letters are significantly different from each other at $p<0.05$ by Duncan's multiple range test.

변화는 $49.22 \mu \mathrm{g} / \mathrm{mL} \rightarrow 205.14 \mu \mathrm{g} / \mathrm{mL}$ 로 가장 크게 증가하였 으며 $5 \%$ 첨가 시에는 $94.39 \mu \mathrm{g} / \mathrm{g} \rightarrow 162.82 \mu \mathrm{g} / \mathrm{g}$ 만큼 증가하 였으며 $10 \%$ 첨가 시에는 $94.99 \mu \mathrm{gg} / \mathrm{mL} \rightarrow 152.61 \mu \mathrm{gg} / \mathrm{mL}$ 로 증가하였다. 즉, 여주를 첨가한 간장 모두 배당체 함량이 감소함에 따라 비배당체 함량이 크게 증가하였으며 total isoflavone 함량 역시 증가하는 결과를 나타내었고 여주를 첨가하지 않은 간장의 total isoflavone 함량이 $216.92 \mathrm{\mu g} / \mathrm{mL}$ 로 가장 높았다.

Isoflavone 화합물 중 배당체 형태가 감소함에 따라 비배 당체 형태가 증가하는 현상은 발효나 숙성 과정 중에 미생 물이 생성하는 산이나 $\beta$-glucosidase 활성에 의한 것으로 보고되었다(17). 대표적인 콩 발효식품인 된장, 청국장, 두 유의 경우에도 발효나 숙성 초기보다는 발효나 숙성 후에 비배당체 isoflavone 화합물 함량이 적게는 약 1.8 배에서 많게는 약 4 배 정도 증가하는 것으로 보고되어있다 $(18,32)$. Marazza 등(33) 콩 발효 연구 결과에서 발효 12시간째 배당 체 함량이 $100 \%$ 감소하였고 비배당체 함량이 크게 증가함 을 보고하였다. 배당체 함량이 감소함에 따라 비배당체 함 량이 증가하는 Marazza 등(33)의 결과는 본 연구와도 유사 하였으나 배당체와 비배당체 함량은 서로 차이점이 있는 것으로 나타났다. 따라서 이러한 결과는 발효 미생물 종류 와 가수분해 효소 활성도 차이, 발효 환경 등 여러 요인에 의해 차이가 있는 것으로 판단된다 $(34,35)$.

여주분말 함유 간장의 항산화 활성 변화

여주분말 함유 간장의 항산화 활성 결과는 Fig. 2 와 같았 다. DPPH 라디칼 소거활성 변화로는 여주를 첨가하지 않은 간장의 경우 초기 $53.65 \%$ 에서 90 일째 $92.58 \%$ 로 크게 증가
하였다. $5 \%$ 첨가 여주 간장도 마찬가지로 $64.03 \% \rightarrow$ $93.96 \%$ 로 크게 증가하였고 $10 \%$ 첨가 여주 간장은 $72.16 \%$ $\rightarrow 96.07 \%$ 로 가장 크게 증가하였다(Fig. 2A). ABTS 라디칼 소거활성 역시 여주 첨가량에 따라 증가하였고 여주를 첨가 하지 않은 간장은 $68.97 \% \rightarrow 95.63 \%$ 의 라디칼 소거활성을 보였고 $5 \%$ 및 $10 \%$ 첨가 간장은 각각 $71.76 \% \rightarrow 96.42 \%$ 및 $75.76 \% \rightarrow 97.27 \%$ 의 소거활성을 나타내었다(Fig. 2B). Hydroxyl 라디칼 소거활성 및 FRAP 환원력 역시 $10 \%$ 첨가 여주 간장이 90 일째 가장 우수하였으며 각각 $59.47 \%$ 와 1.98 의 환원력을 나타내었다(Fig. 2C-D).

$\mathrm{DPPH}$ 와 같은 라디칼 소거활성의 메카니즘은 비라디칼 형태인 DPPH-H 와 수소공여능이 있는 항산화제의 존재 하에서 DPPH 용액이 환원되는 원리에 기초하고 있다(36). 한편 단백질을 원천으로부터 많은 소수성 아미노산을 갖는 peptide 서열은 항산화 활성과 관련이 있는 것으로 보고되 었다(37). 그러므로 본 연구의 여주 간장은 소수성 아미노산 인 phenylalanine, isoleucine, leucine, valine 등이 증가함으 로 라디칼 소거활성에 영향을 미치는 것으로 추정된다. 더 욱이 Eresha Mendis 등(38)은 leucine, valine, 그리고 alanine 과 같은 친수성 및 소수성 아미노산이 리놀레산 모델에서 지방산의 산화를 억제하는데 효과적이라 보고하였고 Suetsuna 등(39)도 glutamic acid, leucine, histidine이 항산화 활성을 향상시키므로 그 중요성을 강조하였다. 이 외 요인 으로 Heim 등(40)의 결과에서는 비배당체 이소플라본이 우수한 항산화 활성을 나타낸다고 보고하였고 특히 daidzein보다는 genistein이 우수하다고 발표한 바 있다. 따 라서 본 연구의 여주 분말 첨가 간장의 향상된 항산화 활성 은 상기 기술된 여러 결과들과 유사한 것으로 판단된다. 

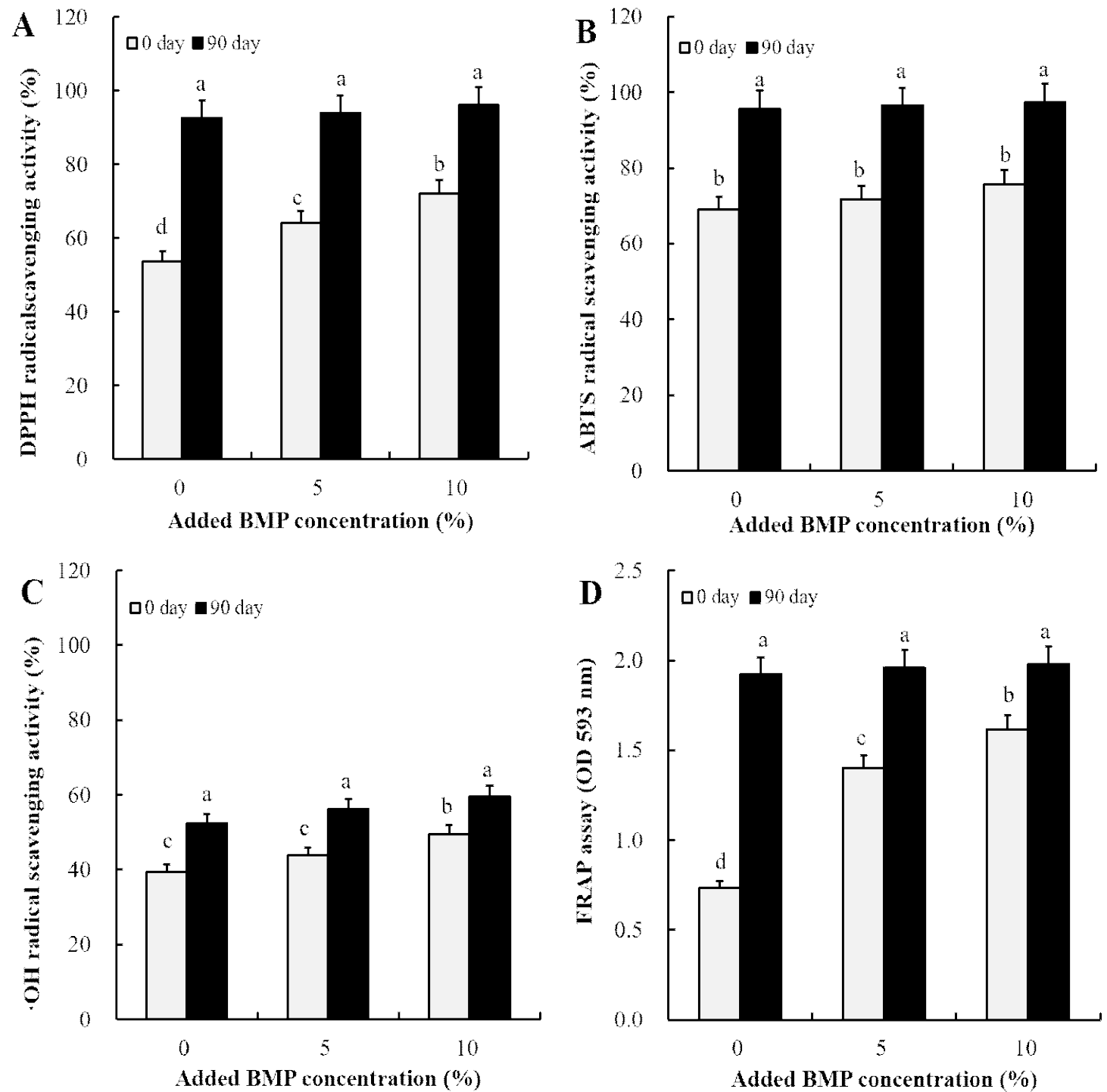

Fig. 2. Comparison of antioxidant activity of soy sauce without and with bitter melon powder (BMP).

(A), DPPH radical scavenging activity; (B), ABTS radical scavenging activity; (C), OH radical scavenging activity; (D), FRAP assay. All values are means of determination in three independent experiments.

All values within a column with different superscript letters are significantly different from each other at $p<0.05$ by Duncan's multiple range test.

여주분말 함유 간장의 탄수화물 분해효소 저해활성 변화

여주분말 함유 간장의 a-glucosidase 저해활성을 측정한 결과는 Fig. 3에 나타낸 바와 같았다. 전체적인 결과로는 $\mathrm{DPPH}$ 라디칼 소거활성과 경향이 일치하는 것으로 나타났 으며 여주 첨가량이 높을수록 초기 탄수화물 저해활성이 증가하였다. 또한 90 일째에는 탄수화물 저해활성이 더욱 증가하여 여주를 첨가하지 않은 경우 $68.51 \%$ 의 비교적 우 수한 활성을 나타내었고 $5 \%$ 첨가 시에는 $76.62 \%$ 를 보였고 $10 \%$ 첨가 시에는 $79.96 \%$ 로 가장 우수한 혈당 강화 효과를 보였다(Fig. 3).

a-Glucosidase는 맥아당을 포도당 단위로 가수분해 시키 는 효소로 분해된 단당류는 인체에 소화 및 흡수됨에 따라 결과적으로 혈당이 상승하게 된다. 그러나 가수분해 효소
활성을 저해시킨다면 당의 흡수율을 떨어뜨릴 수 있으므로 고혈당을 저지함과 동시에 비만 예방 효과를 기대할 수 있다(41). 일반적으로 phenolics 화합물을 함유하고 있는 콩은 그 자체보다는 발효시켰을 시 소화효소 저해활성이 증가한다고 Lee 등(42)은 보고하였고 특히 Behloul와 $\mathrm{Wu}(43)$ 의 연구결과에서는 isoflavone 화합물 중 비배당체 형태인 daidzein과 genistein이 혈당 감소효과가 있음을 보고 하였다. 또한 Xu 등(44)은 토후박 추출물에서 total phenolics 함량과 DPPH 라디칼 소거활성이 높을수록 a-glucosidase 저해활성이 높다고 보고하였고 이는 phenolics 함량과 항당 뇨 활성에 상관관계가 있는 것으로 추측되며 본 연구 결과 와도 유사하였다. 그러나 Ranilla 등(45)의 결과에 따르면 phenolics 함량과 항산화 활성과의 상관관계는 $\mathrm{R}^{2}=0.81$ 로 


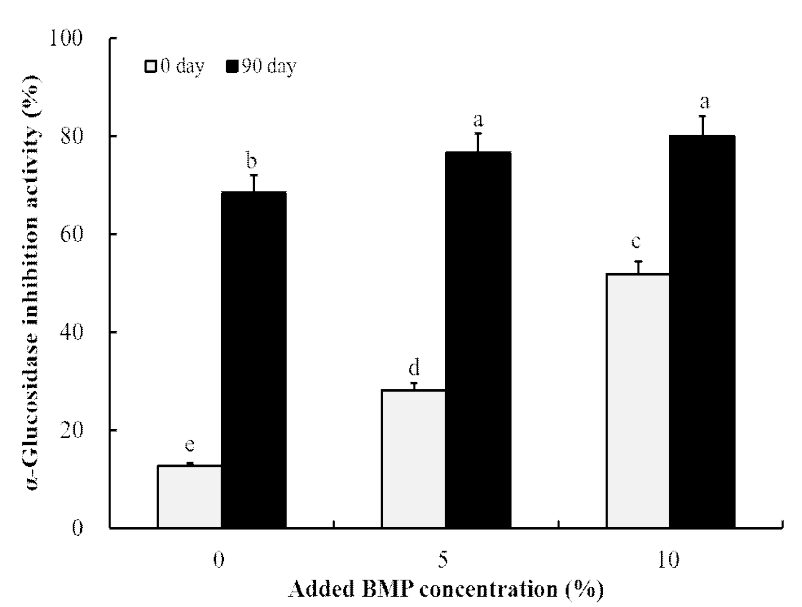

Fig. 3. Comparison of a-glucosidase inhibition activity of soy sauce without and with bitter melon powder (BMP).

All values are means of determination in three independent experiments. All values within a column with different superscript letters are significantly different from each other at $p<0.05$ by Duncan's multiple range test.

높은 유의성을 나타내었으나 항당느 $\left(\mathrm{R}^{2}=0.39\right)$ 활성과는 아 주 낮은 유의성을 나타내 본 연구와는 상이하였다. Park 등(46)의 당뇨유발 모델을 이용한 연구에서는 여주발효 추 출물의 항당뇨 효능을 보고하였다. 좀 더 상세한 결과로는 당뇨모델 마우스의 혈당 수치는 $317 \mathrm{mg} / \mathrm{dL}$ 였으며 유산균 발효 여주 추출물 식이 후에는 $183 \mathrm{mg} / \mathrm{dL}$ 로 뚜렷한 혈당강 화 효과를 나타내었다. 또한 Moon 등(47)은 $70^{\circ} \mathrm{C}$ 에서 $70 \%$ 주정으로 추출한 여주 추출물의 경우 $81.03 \%$ 로 혈당강하제 인 acarbose( $100 \%)$ 에 비해 활성이 높진 않았으나 비교적 우수한 항당뇨 활성을 보고하였다. 특히 항당뇨 활성에 직 접적으로 관여하는 물질은 charantin 또는 momordicin임을 보고하였다. 한편 Park 등(46)은 여주 발효 추출물은 항당뇨 활성을 나타내었으나 여주 열수 추출물 $(339 \mathrm{mg} / \mathrm{dL})$ 또는 여주 에탄올 추출물 $(329 \mathrm{mg} / \mathrm{dL})$ 의 경우에는 명백한 혈당강 화 효과를 나타내지 않는다고 보고하였다. 이러한 결과는 발효 과정에서 항당뇨 기능을 가지는 물질, 즉 charantin 또는 momordicin등의 유효성분이 증가 된 결과로 추측하였 다. 따라서 본 연구 역시 여주에 함유된 charantin 또는 momordicin 물질 함량에 의해 a-glucosidase 저해활성을 보 인 것으로 사료되며 향후 연구에서는 여주 유효성분 변화 확인과 같은 연구가 추가적으로 필요할 것으로 판단된다. 이러한 결과로 a-glucosidase 저해활성은 90 일간의 숙성과 정 중 생성된 phenolics 화합물 또는 비배당체 isoflavone인 daidzein과 genistein 화합물 함량과 높은 상관관계가 있는 것으로 판단된다. 그러므로 본 연구의 여주 분말 첨가 간장 은 향상된 항산화 활성을 가지는 동시에 유용성분(phenolic acid 및 비배당체 isoflavone, 유리아미노산 등) 증대와 탄수 화물 분해효소 저해활성 또한 있으므로 여러 기능성을 포함 한 식품으로 개발될 수 있을 것으로 기대된다.

\section{요 약}

본 연구는 여주 분말 첨가 간장의 기능성 화합물인 phenolic acid(p-hydrobenzoic acid)와 이소플라본(daidzein 및 genistein) 함량 및 항산화 효과를 측정하였다. 여주 분말 $10 \%$ 첨가 간장의 $\mathrm{pH}$ 변화는 $5.83(0 \% \mathrm{BMP}), 5.47(5 \% \mathrm{BMP})$ 및 5.32(10\% $\mathrm{BMP})$ 에서 5.28, 5.36 및 5.16으로 감소하였고, 총산은 반대로 $0.06 \%, 0.07 \%$ 및 $0.09 \%$ 에서 $0.30 \%, 0.28 \%$ 및 $0.36 \%$ 로 증가하였다. 한편 염도는 감소하였고, Bacillus 와 효모의 생균수는 증가하였다. 여주 분말 첨가 간장은 모두 공통적으로 90 일째 isoflavone 배당체 형태가 감소하 는 반면, total phenolics 및 isoflavone 비배당체 함량과 phenolic acid 함량, 항산화 활성 및 탄수화물 분해효소 저해 활성은 증가하였다. 특히 $10 \%$ 여주 분말 첨가 간장의 경우 glutamic acid(GA, 9,876.09 mg/100 mL) 와 $\gamma$-aminobutyric $\operatorname{acid}(\mathrm{GABA}, 325.02 \mathrm{mg} / 100 \mathrm{~mL})$ 함량이 다른 간장들에 비해 높은 것으로 나타났다. 한편 $10 \%$ 여주 분말 첨가 간장은 90 일째 항산화 활성 $(\mathrm{DPPH}, \mathrm{ABTS}, \mathrm{OH}$ 라디칼 소거활성 및 FRAP 환원력)과 a-glucosidase 저해율은 각각 $96.07 \%$, $97.27 \%, 59.47 \%, 1.98$, 및 $79.96 \%$ 로 아주 우수한 활성을 나타내었다.

\section{감사의 글}

본 논문은 농촌진흥청 공동연구사업(과제번호: PJ00846101)의 지원과 농림축산식품부 농생명산업기술개 발사업(과제번호: 314021-03)의 지원에 의해 이루어진 결 과입니다.

\section{References}

1. Kim JS, Kim HO, Moon GS, Lee YS (2008) Comparison of characteristics between soy sauce and black soy sauce according to the ripening period. J East Asian Soc Diet Life, 18, 981-988

2. Lee JH, Chung MG (2011) Determination of optimal acid hydrolysis time of soybean isoflavones using drying oven microwave assisted methods. Food Chem, 129, 577-582

3. Choi YB, Woo JG, Noh WS (1999) Hydrolysis of $\beta$ -glycosidic bonds of isoflavone cojugates in the lactic acid fermentation of soy milk. Korean J Food Sci Technol, 31, 189-195

4. Jackman KA, Woodman OL, Chrissobolis S, Sobey CG (2007) Vasorelaxant and antioxidant activity of the isoflavone metabolite equol in carotid and cerebral 
arteries. Brain Res, 1141, 99-107

5. Shon MY, Lee J, Choi JH, Choi SY, Nam SH, Seo KI, Lee SW, Sung NJ, Park SK (2007) Antioxidant and free radical scavenging activity of methanol extract of Chungkukjang. J Food Composition Anal, 20, 113-118

6. Jeong MK, Bang MH, Seol SM, Kim WK (2002) The effects of isoflavone on lipid metabolism and immune responses in SD rats. Korean J Nutr, 35, 635-642

7. Shin JH, Kang MJ, Yang SM, Lee SJ, Ryu JH, Kim RJ, Sung NJ (2010) Comparison of physicochemical properties and antioxidant activities of Korean traditional Kanjang and garlic added soy sauce. Korean J Agric Life Sci, 44, 39-48

8. Grover JK, Yadav SP (2004) Pharmacological actions and potential uses of Momordica charantia. J Ethnopharmacol, 93, 123-132

9. Kubola J, Siriamornpun S (2008) Phenolic contents and antioxidant activities of bitter gourd (Momoridica charantia L.) leaf, stem and fruit fraction extracts in vitro. Food Chem, 110, 881-890

10. Singh A, Singh SP, Bamezai R (1998) Momordica charantia (bitter gourd) peel, pulp, seed and whole fruit extract inhibits mouse skin papillomagenesis. Tosicol Lett, 94, 37-46

11. Rathi SS, Grover JK, Vats V (2002) The effect of Momordica charantia and Mucuna pruriens in experimental diabetes and their effect on key metabolic enzymes involved in carbohydrate metabolism. Phytother Res, 16, 236-243

12. Parkash A, Ng TB, Tso WW (2002) Purification and characterization of charantin, a napin-like ribosomeinactivating peptide from bitter gourd (Momordica charantia) seeds. J Pept Res, 59, 197-202

13. Schmourlo G, Mendonca-Filho RR, Alviano CS, Costa SS (2005) Screening of antifungal agents using ethanol precipitation and bioautography of medicinal and food plants. J Ethnopharmacol, 96, 563-568

14. Bourinbaiar AS, Lee-Huang S (1995) Acrosin inhibitor, 4'-acetamidophenyl 4-guanidinobenzoate, an experimental vaginal contraceptive with anti-HIV activity. Contraception, 51, 319-322

15. Hamato N, Koshiba T, Pham TN, Tatsumi Y, Nakamura D, Takano R, Hayashi K, Hong YM, Hara S (1995) Trypsin and elastase inhibitors from bitter groud (Momordica charantia LINN) seeds: purification, amino acid sequences, and inhibitory activities of four new inhibitors. J Biochem, 117, 432-437
16. Cho KM, JOO OS (2015) Change in phytoestrogen contents and antioxidant activity during fermentation of Cheonggukjang with bitter melon. Korean J Food Preserv, 22, 119-128

17. Cho KM, Lee JH, Yun HD, Ahn BY, Kimm H, Seo WT (2011) Changes of phytochemical constituents (isoflavones, flavonols, and phenolic acids) during Cheonggukjang soybeans fermentation using potential probiotics Bacillus subtilis CS90. J Food Comp Anal, 24, 402-410

18. Hwang CE, Seo WT, Cho KM (2013) Enhanced antioxidant effect of black soybean by Cheonggukjang with potential probiotic Bacillus subtilis CSY191. Korean J Microbiol, 49, 391-397

19. Aguirre L, Garro MS, de Giori CS (2008) Enzymatic hydrolysis of soybean protein using lactic acid bacteria. Food Chem, 111, 976-982

20. Nishiwaki T, Hayashi K (2001) Purification and characterization of an aminopeptidase from the edible basidiomycete Grifola frondosa. Biosci Biotechnol Biochem, 65, 424-427

21. Yang B, Yang H, Li J, Li Z, Jiang Y (2011) Amino acid composition molecular weight distribution and antioxidant activity of protein hydrolysates of soy sauce lees. Food Chem, 124, 551-555

22. Zarkadas CG, Gagnon C, Gleddie S Khanizadeh S, Cober ER, Guillemette RJD (2007) Assessment of the protein quality of fourteen soybean [Glycine $\max$ (L.) Merr.] cultivars using amino acid analysis and two-dimensional electrophoresis. Food Res Int, 40, 129-146

23. Miliauskas G, Venskutonis PR, Van Beek TA (2004) Screening of radical scavenging activity of some medicinal and aromatic plant extracts. Food Chem, 85, 231-237

24. Lee JH, Seo WT, Cho KM (2011) Dertermination of phytochemical contents and biological activities from the fruits of Elaeagnus multiflora. J Food Sci Nutr, 16, 29-36

25. Pratt DE, Birac PM, Porter WL, Giffee JW (1981) Phenolic antioxidants of soy protein hydrolyzates. J Food Sci, 47, 24-35

26. Seo A, Morr CV (1984) Improved high-performance liquid chromatographic analysis of phenolic acids. J Agric Food Chem, 32, 530-533

27. Boo HO, Lee HH, Lee JW, Hwang SJ, Park SU (2009) Different of total phenolics and flavonoids, radical scavenging activities and nitrite scavenging effects of Momordica charntia L. according to cultivars. Korean 
J Medicinal Crop Sci, 17, 15-20

28. Cho HK, Lee JY, Seo WT, Kim MK, Cho KM (2012) Quality characteristics and antioxidant effects during Makgeolli fermentation by purple sweet potato-rice Nuruk Korean J Food Sci Technol, 44, 728-735

29. Choi MH, Kang JR, Kang MJ, Sim HJ, Lee CK, Kim GM, Kim DG, Shin JH (2016) Quality characteristics and antioxidant activity of soy sauce with added levels of black garlic extract. Korean J Food Cookery Sci, 32, 188-196

30. Jang YJ, Kim EJ, Choi YH, Choi HS, Song J, Choi JH, Park SY (2014) Quality characteristics of Korean traditional Kanjang containing Astragalus memvranaceus. Korean J Food Preserv, 21, 885-891

31. Park SY, Jang YJ, Kim EJ, Choi YH, Choi HS, Choi JH, Song J (2014) Quality characteristics of soy sauce containing Gastrodia elata during fermentation. J East Asian Dietary Life, 24, 875-882

32. Otieno DO, Ashton JF, Shah NP (2006) Evaluation of enzymic potential for biotransformation of isoflavone phytoestrogen in soymilk by Bifidobacterium animalis, Lactobacillus acidophilus and Lactobacillus casei. Food Res Int, 39, 394-407

33. Marazza JA, Nazareno MA, de Giori GS, Garro MS (2012) Enhancement of the antioxidant capacity of soymilk by fermentation with Lactobacillus rhamnosus. J Funct Foods, 4, 594-601

34. Chien HC, Huang HY, Chou CC (2006) Transformation of isoflavone phytoestrogens during the fermentation of soymilk with lactic acid bacteria and bifidobacteria. Food Microbiol, 23, 772-778

35. Donkor ON, Shah NP (2008) Production of $\beta$-glucosidase and hydrolysis of isoflavone phytoestrogen by Lactobacillus acidophilus, bifidobacterium lactis, and Lactobacillus casei in soymilk. J Food Sci, 73, 15-20

36. Yang B, Zhao MM, Shi J, Yang N, Jiang YM (2008) Effect of ultrasonic treatment on the recovery and DPPH radical scavenging activity of polysaccharides from longan fruit pericarp. Food Chem, 106, 685-690

37. Chen HM, Muramoto K, Yamauchi F (1995) Structural analysis of antioxidative peptides from soybean $\beta$ -conglycinin. J Agric Food Chem, 43, 574-578
38. Eresha Mendis NR, Jung WK, Je JY, Kim SK (2005) Purification of a radical scavenging peptide from fermented mussel sauce and its antioxidant properties. Food Res Int, 38, 175-182

39. Suetsuna K, Ukeda H, Ochi H (2000) Isolation and characterization of free radical scavenging activities peptides derived from casein. J Nutr Biochem, 11, 128-131

40. Heim KE, Tagliaferro AR, Bobilya DJ (2002) Flaovnoid antioxidants: Chemistry, metabolism and structure-activity relationships. J Nutr Biochem, 13, 572-584

41. Mai TT, Thu NN, Tien PG, Chuyen NV (2007) Alpha-glucosidase inhibitory and antioxidant activities of Vietnamese edible plants and their relationships with polyphenol contents. J Nutr Sci Vitaminol, 53, 267-276

42. Lee BH, Lo YH, Pan TM (2013) Anti-obesity activity of Lactobacillus fermented soy milk products. J Funct Foods, 5, 905-913

43. Behlou N, Wu G (2013) Genistein: A promising therapeutic agent for obesity and diabetes treatment. Eur J Pharmacol, 698, 31-38

44. Xu ML, Wang L, Kim HS, Jin CW, Cho DH (2010) Antioxidant and anti-diabetes activity of extracts from Machilus thunbergii S.et Z. Korean J Medicinal Crop Sci, 18, 34-39

45. Ranilla LG, Kwon YI, Apostolidis E, Shetty K (2010) Phenolic compounds, antioxidant activity and in vitro inhibitory potential against key enzymes relevant for hyperglycemia and hypertension of commonly used medicinal plants, herbs and spices in Latin. Bioresour Technol, 101, 4676-4689

46. Park HS, Kim WK, Kim HP, Yoon YG (2015) The efficacy of lowering blood glucose levels using the extracts of fermented bitter melon in the diabetic mice. J Appl Biol Chem, 58, 259-265

47. Moon JH, Choi DW, Kim SE, Seomoon JH, Hong SY, Kim HK, Cho KM, Song J, Kang SS, Kim KH, Kwon OK (2015) Comparison of biological activities of ethanol extracts of unripe fruit of bitter melon (Momordica charantia L.) cultivated in Hamyang, Korea. J Korean Soc Food Sci Nutr, 44, 1637-1644 